\title{
Changes in the plankton community passing a Mytilus edulis mussel bed
}

\author{
Fredrik Norén ${ }^{1, *}$, Joel Haamer ${ }^{2}$, Odd Lindahl ${ }^{3}$ \\ ${ }^{1}$ Dept. of Marine Botany, Box 46, 40530 Göteborg, Sweden \\ ${ }^{2}$ National Board of Fisheries, Institute of Coastal Research, Nya varvet, 42671 Västra Frölunda, Sweden \\ ${ }^{3}$ Kristineberg Marine Research Station, 45034 Fiskebäckskil, Sweden
}

\begin{abstract}
The changes in phytoplankton community in water passing a large natural population of the blue mussels Mytilus edulis L. in the Öresund strait between Malmö and Copenhagen were studied. Changes in both the biomass and composition of the phytoplankton community were detected and an explanation invoking intense grazing pressure from the mussels is proposed. The biomass, measured as biovolume, decreased from 0.42 to $0.11 \mathrm{~mm}^{3} \mathrm{l}^{-1}$ ( $74 \%$ decrease) as the non-stratified turbulent water passed the mussel bed over a distance of $20 \mathrm{~km}$. Beyond the mussel bed, biomass increased to $0.39 \mathrm{~mm}^{3} \mathrm{l}^{-1}$ within $27 \mathrm{~km}$. A benthic filter-feeder model was adapted to correlate the theoretical maximum filtration with observations. The model was in accordance with observed values if a filtration efficiency of $25 \%$ was applied. During the passage the phytoplankton community was shifted to smaller phytoplankton cells: phytoplankton with a diameter of 2 to $12 \mu \mathrm{m}$ increased from 65 to $89 \%$ of the total phytoplankton community and all other plankton taxa declined. This observed shift in community was significant correlated with a predicted shift due to the mussel filtration.
\end{abstract}

KEY WORDS: Benthic-pelagic coupling · Oresund · Grazing impact · Phytoplankton · Community structure - Modelling

\section{INTRODUCTION}

The grazing effect of benthic filter-feeders on plankton communities has been studied extensively by several researchers. The main effect is that particulate matter is removed from the water column. This has been shown in marine habitats (e.g. Wright et al. 1982, Carlson et al. 1984, Nichols 1985, Loo \& Rosenberg 1989, Asmus \& Asmus 1991, Møhlenberg 1995) and in freshwater (Cohen et al. 1984, MacIsaac et al. 1992, Lavrentyev et al. 1995, Roditi et al. 1996). In this study we adapted a benthic filter-feeder model from Riisgård et al. (1998) to test if the theoretical maximum filtration by the mussels was in accordance with observed values.

Benthic filter-feeders may also affect the plankton community structure. If there is a non-selective grazing pressure on the plankton community, which we

- Present address: Kristineberg Marine Research Station, 45034 Fiskebäckskil, Sweden. E-mail: f.noren@kmf.gu.se assume for particles $>4 \mu \mathrm{m}$ (Møhlenberg \& Riisgård 1978), this will skew the community towards more fastgrowing species. The more intense non-selective grazing is, the more faster-growing algae will dominate. Small algae have an advantage under such circumstances in that they grow faster and can outgrow larger algae, which grow more slowly (Caraco et al. 1997). This has been shown for salp grazing in New Zealand waters (Zeldis et al. 1995). Under experimental conditions a community change towards smaller algae resulting from grazing by filter-feeders has been shown by Prins et al. (1995) and Olsson et al. (1992).

In this study the observed shift in plankton community is compared to a theoretical prediction of community shift. This theoretical modelled community shift comes from a near maximum growth of all plankton groups, small versus larger, in a state of no resource limitation. The main idea, and hypothesis, is that the intense grazing from mussels is making a resource free to use for plankton growth where the small plankton, i.e. faster-growing, have a competitive advantage. 


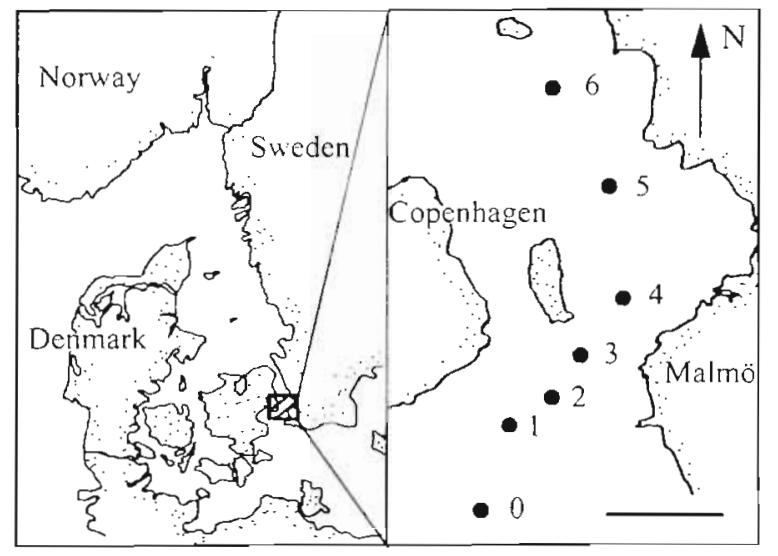

Fig. 1 Area investigated and sampling stations. Scale bar = $10 \mathrm{~km}$

The present study was conducted in the Oresund sill area (The Sound, Fig. 1) and investigated phytoplankton biomass and community structure in the water passing a bed of blue mussels Mytilus edulis L. It is suitable to study these kinds of large-scale changes in Orresund since there is a large and defined mussel bed (SEMAC JV, 1997), and a frequently occurring spring situation with a uni-directional flow of the current under turbulent and non-stratified conditions. During this study the hydrography was more extensively studied in a parallel survey (Haamer et al. unpubl.) which demonstrated that the water was well mixed and that there was a steady northward current during the sampling period

This study aims to test if the plankton community passing a mussel bed changes in the following ways: (1) The biomass of phytoplankton is reduced during passage in a manner directly dependent of the intensity of the mussel grazing. (2) There should be a shift in the plankton community structure towards smaller and faster-growing species.

\section{MATERIALS AND METHODS}

Area investigated. The Öresund is 1 of 3 straits connecting the Baltic sea with the Kattegat where 25 to $30 \%$ of the Baltic outflow passes (Fig. 1). The sill in Öresund is situated between Copenhagen and Malmö and has a cross-sectional area of approximately $6 \times 10^{4} \mathrm{~m}^{2}$. The sill area, where the depth is between 3 and $8 \mathrm{~m}$, is about $170 \mathrm{~km}^{2}$ and the length of the sill in a north-south direction is $15 \mathrm{~km}$. The substrate of the sill area consists of limestone, boulders, stones and coarse sand with no fine material-a typical transport bottom. The shallow sill accelerates the water, which results in turbulent mixing of the water from the bottom to the surface.
Hydrography and mixing. The investigations were carried out on the RV 'Skagerak', 13 and 14 May 1997. Stns 1, 2, 3 and 4 (Fig. 1) were sampled twice the first day and on 1 occasion together with Stns 0, 5, and 6 the second day. Salinity and temperature were measured with a CTD (Neil Brown MK5) every second meter from $0.5 \mathrm{~m}$ depth down to the bottom. A prevailing northward current during both days ranged from 0.28 to $0.60 \mathrm{~m} \mathrm{~s}^{-1}$ with a weighted mean value of $0.38 \mathrm{~m} \mathrm{~s}^{-1}$; current values are taken from Haamer et al. (unpubl.) and are shown in Table 1. According to Edler (1977) there is a prevailing current in this area $160 \%$ of the time there is a northerly current with a mean speed of $0.46 \mathrm{~m} \mathrm{~s}^{-1}$ ). The vertical mixing was measured by comparing chlorophyll a (chl a) (Haamer et al. unpubl.) in water samples taken near the surface at a depth of $2 \mathrm{~m}$ and near the bottom at a depth of $7 \mathrm{~m}$. A paired t-test was used with data from Stns 1, 2, 3 and 4, from the first transect on 13 May and from the transect 14 May. The mixing was strong enough to ensure that there was no difference in chl a concentration between surface and bottom waters ( $\mathrm{p}=0.75, \mathrm{n}=8$ pairs).

Mussel densities and area-specific population filtration. Mussels occur in the whole area with the highest population densities between Copenhagen and Malmö (Fig. 1, Stns 1 to 4), where the mean biomass was found to be $128 \pm 61$ (SD) $\mathrm{g} \mathrm{m}^{-2}$ (shell free dry weight [SFDW]), the mean length of the mussels was estima-ted as $11.9 \pm 1.23 \mathrm{~mm}$, the mean weight per mussel as $5.2 \pm 1.7 \mathrm{mg}$ (SFDW) and the mean abundance as $24100 \pm 7800 \mathrm{~m}^{-2}$. South of this dense mussel bed (Stn 0 ) the mean mussel biomass was estimated as $67 \pm 64 \mathrm{~g} \mathrm{~m}^{-2}$ (SFDW), the mean length of the mussels was estimated as $13.1 \pm 3.1 \mathrm{~mm}$, the mean weight per mussel as $7.7 \pm 4.0 \mathrm{mg}$ (SFDW) and the mean abundance as $7200 \pm 6100 \mathrm{~m}^{-2}$. All data are from SEMAC JV (1997), who made extensive surveys of the mussel biomass from the area during October 1996. Data are compiled from their transects closest to our sampling stations ( $\mathrm{n}=3$ for $\operatorname{Stn} 0$, and $\mathrm{n}=14$ for Stns 1 to 4 ).

The individual filtration rate $\left(F_{\text {ind }} \mathrm{ml} \mathrm{h}^{-1}\right.$ ind. $\left.{ }^{-1}\right)$ was calculated according to Risgărd et al. (1980): $F_{\text {ind }}=$ $0.025 W^{i .03}$, where $W$ is the SFDW $(\mu g)$ taken from SEMAC JV (1997), who measured SFDW at each SEMAC station. The area-specific population filtration

Table 1. Current speeds during 3 sampling transects and the distance between sampling stations

\begin{tabular}{|c|c|c|c|c|c|c|}
\hline $\begin{array}{l}\text { Station } \\
\text { Distance }(\mathrm{km})\end{array}$ & 7 & 3 & 4 & $7^{4}$ & $10^{5}$ & $17^{6}$ \\
\hline \multicolumn{7}{|l|}{ Current $\left(\mathrm{m} \mathrm{s}^{-1}\right)$} \\
\hline 13 May no. 1 - & 0.28 & 0.28 & 0.45 & 0.31 & - & - \\
\hline 13 May no. 2 - & 0.45 & - & 0.35 & 0.32 & - & - \\
\hline 14 May $\quad 0.28$ & 0.42 & 0.40 & 0.40 & 0.60 & 0.51 & 0.23 \\
\hline
\end{tabular}


rate $\left(F_{\text {pop }}, \mathrm{m}^{3} \mathrm{~m}^{-2} \mathrm{~h}^{-1}\right)$ was estimated by multiplying the individual filtration rate by the abundance (ind. $\mathrm{m}^{-2}$ ) of Mytilus edulis.

Modelling the impact of Mytilus edulis on plankton biomass. Between Stn 0 and Stn 4, a model to describe the theoretical filtering by mussels was adapted after Riisgård et al. (1998), who used this model in a shallow Danish estuary to model the impact of the ascidian Ciona intestinalis on plankton biomass

$$
C_{x}=C_{0} \mathrm{e}^{-[h]}
$$

where $C_{x}=$ algal concentration $\left(\mathrm{mm}^{3} \mathrm{l}^{-1}\right)$ at downstream distance $x, C_{0}=$ initial algal concentration, $f$ (dimensionless velocity scale $)=F_{\text {pop }} / v_{c}\left(F_{\text {pop }}=\right.$ areaspecific population filtration rate, $V_{C}=$ current velocity), $l$ (dimensionless length scale) $=x / Y(Y=$ depth of mixed bottom layer, which, in the present study, was assumed to be equal to the mean depth at the bottom). Eq. (1) illustrates how the algal concentration decreases as a function of the dimensionless scales for velocity and length.

To make a 'best-fit' of the model to observed values an efficiency coefficient ( $\eta$ ) of $F_{\text {pop }}$ was calculated and added to the equation:

$$
C_{x}=C_{0} \mathrm{e}^{-(f / n) !}
$$

This was made by iteration calculus of $\eta$. The best value of $\eta$ was chosen through 1 -way repeated measures ANOVA (SigmaStat software). The values of SS (sum of squares) of the difference between observed and modelled values was calculated between different $\eta$ and the $\eta$ which rendered the lowest SS was chosen.

Plankton biomass and community structure. For Stns 0 to 4 , the phytoplankton samples were taken with a flexible segmented hose from the surface down to $0.1 \mathrm{~m}$ above the bottom. Replication of the hose sampling was 3 -fold at each station; the replicates were taken within 10 min, while the ship was drifting. At Stn 5 the water mass was stratified and samples were taken from 0 to $5 \mathrm{~m}$; at $\operatorname{Stn} 6$ samples were taken from 0 to $8 \mathrm{~m}$ depth in order to avoid sampling of water that had not passed the mussel bed, i.e. with different origin. From each hose sample, 1 well-mixed subsample of $100 \mathrm{ml}$ was taken and immediately preserved with $1 \mathrm{ml}$ acidified Lugol's iodine.

The samples were analysed, in randomized order, according to the Utermöhl method (Utermöhl 1958) using a sedimentation volume of $50 \mathrm{ml}$. The samples were left to settle for $24 \mathrm{~h}$. For identification and counting, species $>12 \mu \mathrm{m}$ (maximal axis length) were analysed at $100 \times$ and $200 \times$ magnification and species $<12 \mu \mathrm{m}$ at $400 \times$ magnification. The picoplankton $(<2 \mu \mathrm{m})$ were beyond the resolution of the light microscope and were not included in this study. Biovolumes were calculated as geometric bodies according to
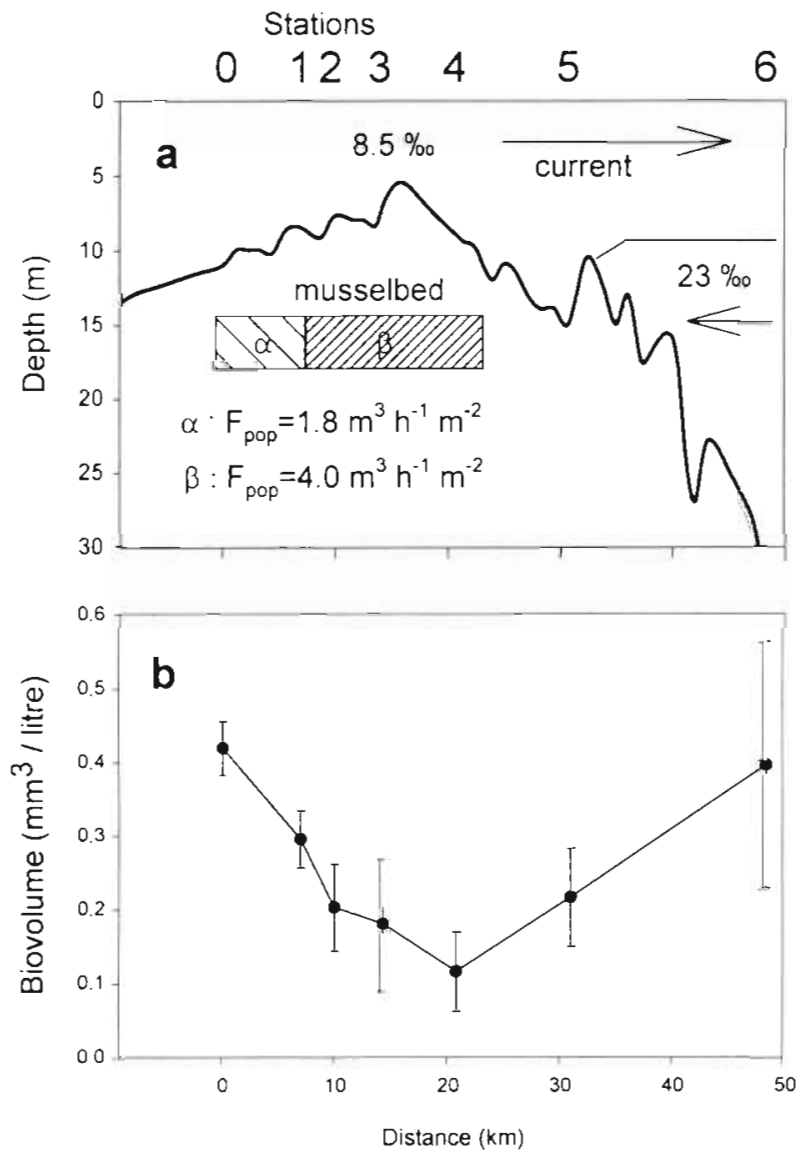

Fig. 2. (a) Decrease of plankton biomass (= biovolume) as the water is passing the mussel bed shows the current direction and salinity profiles measured at each station. $F_{\text {pop }}$ : areaspecific filtration rate for the 2 estimated mussel densities at the bed. (b) Decrease in biomass (= biovolume) during transport over the mussel bed. Stns 0,5, $6(\mathrm{n}=3)$; Stns 1, 2, 3 $(n=9) ;$ and $\operatorname{Stn} 5(n=8)$

Hansen (1992), and used as a measurement of the biomass (Edler 1977). The phytoplankton was grouped into the following taxa: Cells 2 to $12 \mu \mathrm{m}$, Ciliates, Dinoflagellates and Others. The group Cells 2 to $12 \mu \mathrm{m}$ was made up of all cells with a diameter in main axis between 2 and $12 \mu \mathrm{m}$. Most abundant in this group were members of cryptophyceae, dinophyceae and chlorophyceae. The group Others consisted of diatoms, cyanobacteria and non-specified.

The change in plankton community structure along the transect (Stns 0 to 6 ) was measured as the proportion of total biovolume in regard to the 4 groups: Cells 2 to $12 \mu \mathrm{m}$, Ciliates, Dinoflagellates and Others. Due to unequal sample size, 3 replicates were randomly taken from each station. The statistical test for significant changes was a linear regression for each plankton group after arcsine transformation.

Modelling the plankton community change. The theoretical modelling of the community shift from 

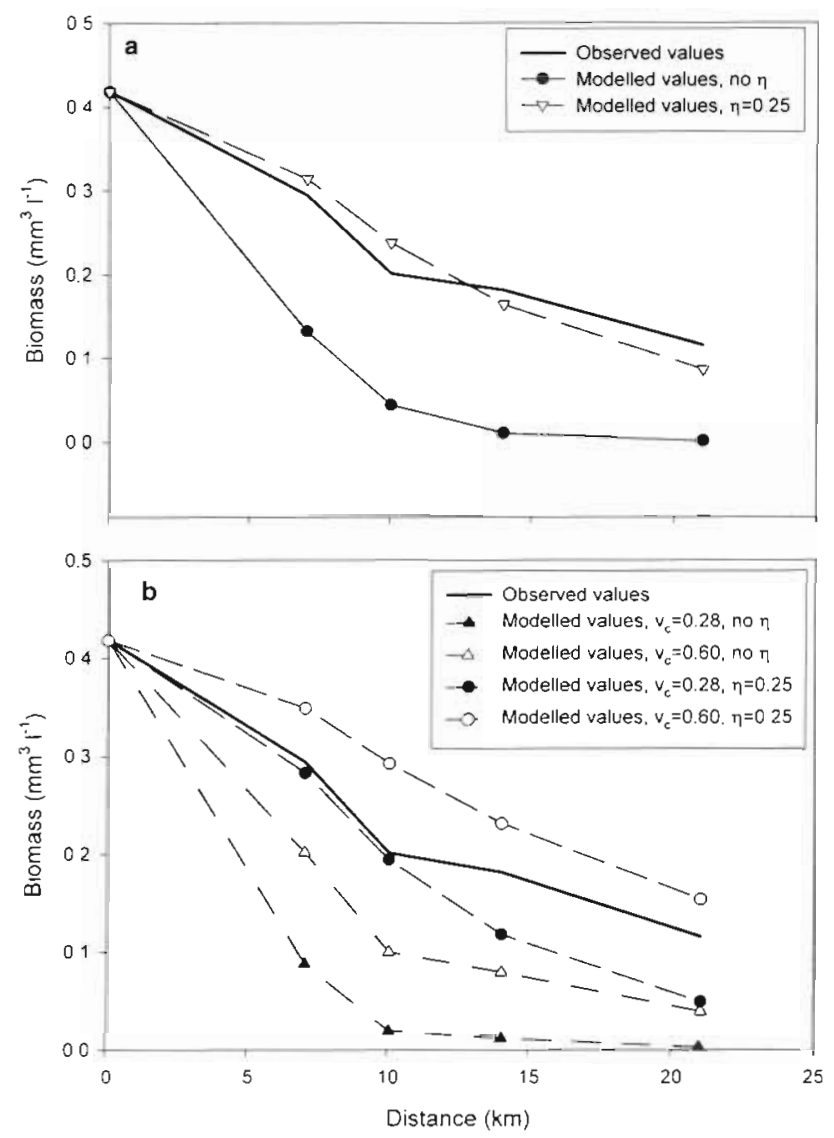

Fig. 3. Modelled values of plankton biomass during the transport over the mussel bed (Stn 0 to Stn 4). (a) Observed values compared with modelled values using mean current $\left(V_{\mathrm{c}}=\right.$ $0.38 \mathrm{~m} \mathrm{~s}^{-1}$ ) and the efficiency coefficient $\eta$, or not (b) Observed values compared with modelled values using minimum and maximum current velocities in combination with or without the efficiency coefficient $\eta$

Stns 0 to 6 was based on an allometric growth dependency for protist plankton (i.e. growth is size dependent and increases with decreasing size) and cellular volume is used as the base of allometric growth. Tang (1995) used an equation to estimate the growth rates between the different size fractions:

$$
\mu=3.49 \mathrm{VOL}^{-0.16}\left(\mathrm{r}^{2}=0.34, \mathrm{n}=126\right)
$$

where $\mu$ is the intrinsic growth rate $\left(\mathrm{d}^{-1}\right)$ and VOL is, in this case, the estimated volume in $\mu \mathrm{m}^{3}$. This results in a growth rate of the small cells (Cells 2 to $12 \mu \mathrm{m}$ ) with a mean volume of $113 \mu^{3}$ (diameter $6 \mu \mathrm{m}$ ) of $1.64 \mathrm{~d}^{-1}$. The ciliates with a mean volume of $4200 \mu \mathrm{m}^{3}$ (diameter $20 \mu \mathrm{m}$ ) have a growth rate of $0.92 \mathrm{~d}^{-1}$ and larger cells with a volume of $14100 \mu^{3}$ (diameter $30 \mathrm{~m}$ ) have a growth rate of $0.75 \mathrm{~d}^{-1}$. These growth rates were inserted into a standard equation for exponential growth

$$
C_{x}=C_{0} \mathrm{e}^{\mu t}
$$

where $C_{0}=$ observed biomass values $\left(\mathrm{mm}^{3} \mathrm{l}^{-1}\right)$ at $\operatorname{Stn} 0$, $C_{x}=$ modelled biomass at distance $x, \mu=$ growth rates $\left(\mathrm{d}^{-1}\right)$ for each size group and $t=$ time (days) calculated from the mean current and distance. The modelled biomass for each size group was calculated as the percent of total plankton biomass (i.e. Cells 2 to $12 \mu \mathrm{m}$, Ciliates and Larger cells) and start values were taken from observed values at Stn 0 . The size group Larger cells is equal to the sum of the groups Dinoflagellates and Others in the analysis of observed community shift. A Pearson correlation (SigmaStat software) was run to test the difference between observed and modelled values of the community shift.

\section{RESULTS}

\section{Hydrography}

The salinity was 8.5 psu at all depths for Stns 0 to 4 on both days (13 and 14 May). On the second day, Stns 5 and 6 were also sampled and there was a distinct halocline between 8.5 and 23 psu at $9 \mathrm{~m}$ depth (Fig. 2a). This was a result of the presence of deeper, more saline Kattegat water. The temperature ranged from 7.5 to $8.0^{\circ} \mathrm{C}$ at Stns 0 to 4 in the whole water column and for Stns 5 and 6 above the halocline.

\section{Plankton biomass}

During the passage over the mussel bed the biomass of phytoplankton declined from $0.42 \pm 0.04( \pm \mathrm{SD}) \mathrm{mm}^{3}$ $\mathrm{l}^{-1}$ at Stn 0 to $0.11 \pm 0.05 \mathrm{~mm}^{3} \mathrm{l}^{-1}$ at Stn 4 (Fig 2b). After Stn 4 the biomass in the surface water increased to $0.39 \pm 0.17 \mathrm{~mm}^{3} \mathrm{l}^{-1}$ at $\operatorname{Stn} 6$.

The model was run using both Eq. (1) and, with correction of $\eta=0.25$, Eq. (2), with the following values: $C_{0}=0.42 \mathrm{~mm}^{3} \mathrm{l}^{-1}$, biomass at $\operatorname{Stn} 0_{;} F_{\text {pop }}=1.8 \mathrm{~m}^{3} \mathrm{~m}^{-2} \mathrm{~h}^{-1}$ for $\operatorname{Stn} 0$ and $F_{\text {pop }}=4.0 \mathrm{~m}^{3} \mathrm{~m}^{-2} \mathrm{~h}^{-1}$ for Stns 1 to $4 ; v_{\mathrm{c}}=$ $0.38 \mathrm{~m} \mathrm{~s}^{-1}$ (mean current), $v_{\mathrm{c}}=0.28 \mathrm{~m} \mathrm{~s}^{-1}$ (min. current), $v_{c}=0.60 \mathrm{~m} \mathrm{~s}^{-1}$ (max. current); and $Y=8 \mathrm{~m}$, which is the mean depth between Stn 0 and $\operatorname{Stn} 4$.

The result of the modelling is shown in Figs $3 a, b$. In Fig. 3a the difference in using the efficiency coefficient $(\eta)$ in an equation based on mean $V_{c}$ is shown; in Fig. $3 b$ the difference of using maximum and minimum current velocities and $\eta$ or not in an equation is shown.

\section{Plankton community structure}

A continuous shift in the plankton community towards smaller algae was found along the transect. The group Cells 2 to $12 \mu \mathrm{m}$ increased significantly 

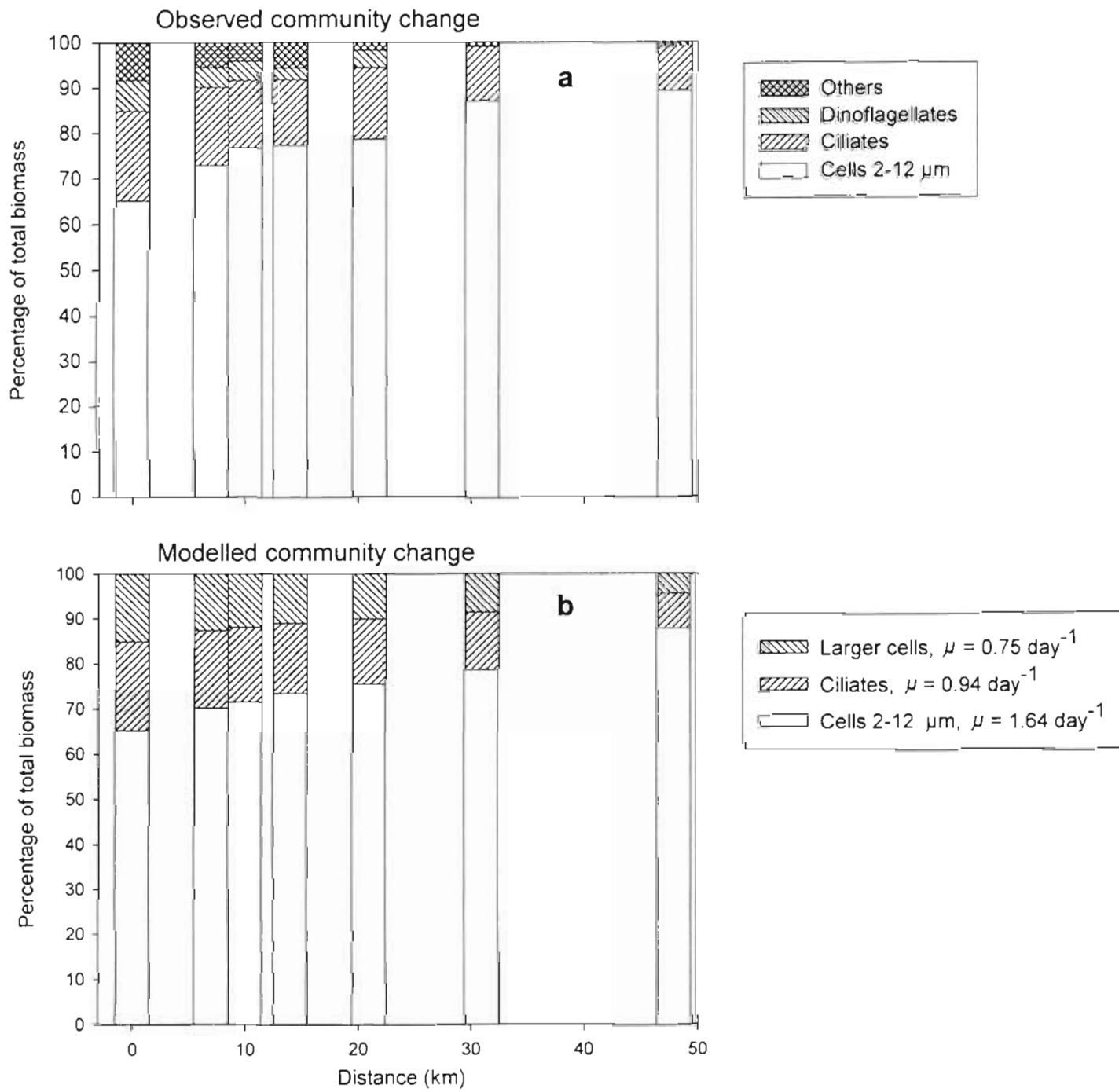

Fig. 4. Plankton community change during transport over the mussel bed. (a) Observed community change as proportions of the 4 groups. (b) Modelled community change as proportions of 3 size classes (Cells 2 to $12 \mu \mathrm{m}$ : mean diameter $6 \mu \mathrm{m}$; Ciliates: mean diameter $20 \mu \mathrm{m}$; Larger cells: mean diameter $30 \mu \mathrm{m}$ ) with different intrinsic growth rates $(\mu)$. Start value for the modellation was from observed values at Stn 0

Table 2. Plankton community change between the first and last station ( $\mathrm{n}=3$ each). Regression analysis comprises data from all stations $(n=21)$. - no test done

\begin{tabular}{|c|c|c|c|c|c|c|c|}
\hline & \multicolumn{2}{|c|}{ Mean values $(\%) \pm S D$} & \multicolumn{5}{|c|}{ Regression analysis } \\
\hline & $\operatorname{Stn} 0$ & $\operatorname{Stn} 6$ & p-value & Power & $r^{2}$ & $\mathrm{a}$ & $\mathrm{b}$ \\
\hline Cells 2 to $12 \mu \mathrm{m}$ & $65.2 \pm 9.3$ & $89.4 \pm 3.5$ & $<0.01$ & 0.95 & 0.48 & 73.1 & 0.86 \\
\hline Ciliates & $19.7 \pm 4.2$ & $9.8 \pm 3.4$ & 0.12 & 0.33 & 0.12 & 17.1 & -0.15 \\
\hline Dinoflagellates & $6.9 \pm 3.4$ & $0.5 \pm 0.4$ & $<0.01$ & 0.92 & 0.44 & 5.5 & -0.1 \\
\hline Others & $8.2 \pm 7.4$ & $0.3 \pm 0.1$ & - & - & - & - & - \\
\hline
\end{tabular}

$(p<0.001)$ during the passage, from $65.2 \pm 9.3 \%( \pm \mathrm{SD})$ of total biomass at Stn 0 to $89.4 \pm 3.5 \%$ at Stn 6 (Fig. 4, Table 2). The dinoflagellates declined significantly $(p=0.01$ ) from $6.9 \pm 3.4$ to $0.5 \pm 0.4 \%$. The decline in ciliates from $19.7 \pm 4.2$ to $9.8 \pm 3.4 \%$ was not statistically significant $(p=0.12)$. These regressions were tested and passed for normal distributed variances and homoscedasticity $(\mathrm{p}<0.05)$. For the rest of the plank- 


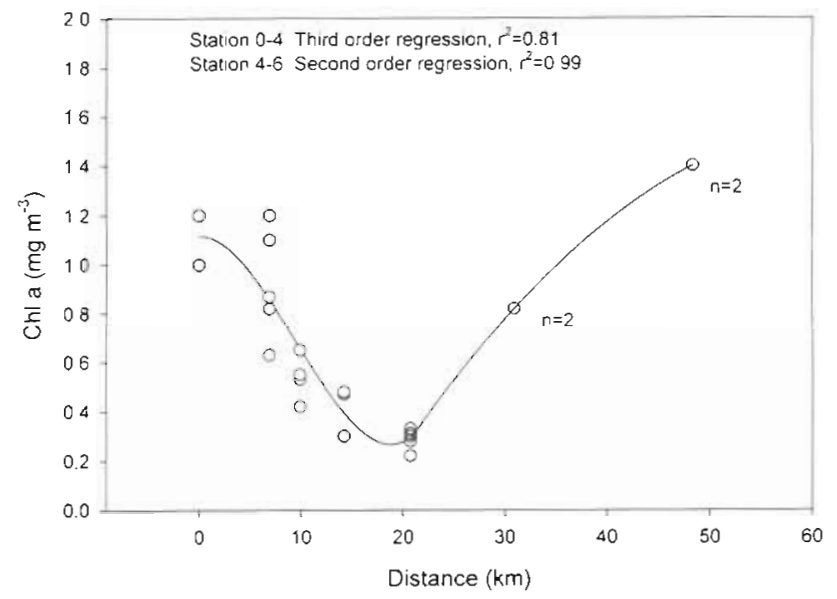

Fig. 5. Changes in chl a concentration during transport over the mussel bed. Data from Haamer et al. (unpubl.)

ton community (Others) no test could be done since the variances were not normally distributed and there was no homoscedasticity between the variances.

The modelling of community change was run using the following values: Cells 2 to $12 \mu \mathrm{m}: C_{0}=0.42 \mathrm{~mm}^{3}$ $\mathrm{l}^{-1} \times 65.2 \%=0.273 \mathrm{~mm}^{3} \mathrm{l}^{-1}, \mu=1.64 \mathrm{~d}^{-1}$; Ciliates: $C_{0}=$ $0.42 \mathrm{~mm}^{3} \mathrm{l}^{-1} \times 19.7 \%=0.083 \mathrm{~mm}^{3} \mathrm{l}^{-1}, \mu=0.92 \mathrm{~d}^{-1}$; Larger cells: $C_{0}=0.42 \mathrm{~mm}^{3} \mathrm{l}^{-1} \times 15.1 \%=0.063 \mathrm{~mm}^{3} \mathrm{l}^{-1}$, $\mu=0.75 \mathrm{~d}^{-1}$. For values of $t$, the distance between the stations was divided with the current speed from Transect 2, 14 May, see Table 2 .

The result of modelling is shown in Fig. 5. Cells 2 to $12 \mu \mathrm{m}$ increased from 65.2 to $87.8 \%$, Ciliates decreased from 19.7 to $7.8 \%$ and Larger cells decreased from 15.1 to $4.5 \%$. There was a significant correlation between modelled and observed values for all 3 size groups (Pearson correlation, $\mathrm{n}=7$ ): For Cells 2 to $12 \mu \mathrm{m}, \mathrm{r}=0.945$, for Ciliates $\mathrm{r}=0.936$ and for Larger cells, $r=0.933$.

\section{DISCUSSION}

\section{Plankton biomass and modelling}

The mussel bed of Öresund clearly reduced the phytoplankton biomass during the passage over the sill. The high turbulence and lack of stratification made it possible for the mussels to filter all the water passing, as is assumed in this study, and not just the bottom layer. Otherwise, the situation is more complicated with different layers of water, and a more sophisticated model of benthic filtering impact has to be used (Frechette et al. 1989).

North of Stn 4, the water column was stratified with a halocline. This is the reason for the increase of bio- mass after Stn 4, since the upper water layer was not in direct contact with the bottom and the plankton were able to have rapid growth without grazing from benthic filter-feeders. A calculation was done to test if this is reasonable: if the growth rate needed ( $\mu_{\text {needed }}$ ) to give the rise in biomass from Stns 4 to 6 is calculated from Eq. (3) $\left(C_{x}=0.39 \mathrm{~mm}^{3} \mathrm{l}^{-1}, C_{0}=0.11 \mathrm{~mm}^{3} \mathrm{l}^{-1}\right.$ and $t=1.08 \mathrm{~d}_{i}$ retention time calculated from transect 2,14 May, see Table 1 ) it gives $\mu_{\text {needed }}=1.17 \mathrm{~d}^{-1}$. This value of growth rate is a realistic value for a plankton community dominated by small cells (Furnas 1990).

The chl a results (Haamer et al. 191 unpubl.) followed the same pattern as the biovolume measurements (Fig. 5). The chl a was declined from $1.1 \mathrm{mg}$ chl $a \mathrm{~m}^{-3}$ at $\mathrm{Stn} 0$ to $0.3 \mathrm{mg}$ chl $a \mathrm{~m}^{-3}$ at $\mathrm{Stn} 4$. After Stn 4 the chl a concentration rose to $1.4 \pm \mathrm{SD} \mathrm{mg}$ chl a $\mathrm{m}^{-3}$ again.

The result of the modelling is in accordance with the observed values of phytoplankton biomass after application of an efficiency coefficient, $\eta_{i}$ otherwise the model predicted values of plankton biomass that were too low. This coefficient can be seen as the momentary efficiency of the filter-feeders on the water column. This factor is dependent on the factors involved at every specific survey so a general $\eta$ cannot be stated from this study. The $\eta$-value is dependent on the current velocity; we used the mean current $\left(0.38 \mathrm{~m} \mathrm{~s}^{-1}\right)$ to calculate $\eta$ which gave us $\eta=0.25$, if we use the minimum current $\left(0.28 \mathrm{~m} \mathrm{~s}^{-1}\right\}$ this gives us $\eta=0.18$ and if we use the maximum current $\left(0.60 \mathrm{~m} \mathrm{~s}^{-1}\right)$ this gives us $\eta=0.40$. In those different values the hydrodynamical characters as boundary layer (increases with slower current and hence lower the filtering efficiency for the mussels) and turbulence are included. The efficiency coefficient, $\eta$, could also be viewed as: (1) a factor that corrects for internal variances in the area-specific population filtration rate $F_{\text {pop }}$. The variance in $F_{\text {pop }}$ consists of both the imprecision in estimating mussel abundance, which is a great source of variance, and the variance of individual filtration rate per mussel, which is not necessarily the same in the laboratory as in nature; (2) a factor that invokes the re-filtering of water by the mussels. Some fraction of the water filtered by one mussel is also processed by neighbouring mussels.

The effect of the small mussel sizes on the filtering efficiency was excluded, since they filter particles larger than $4 \mu \mathrm{m}$ at $100 \%$ efficiency regardless of size (Møhlenberg \& Riisgård 1978). The filtering capacity per gram of mussel, on the other hand, is larger for smaller mussels, and this is included in the calculation of the filtration capacity. The $F_{\text {pop }}$ in this study was lower than other mussel beds according to Jørgensen (1990), who reported filtration rates of 6 to $12 \mathrm{~m}^{3} \mathrm{~m}^{-2}$ $\mathrm{h}^{-1}$. The reason for this could be that Jørgensen (1990) reported only maximal filtration rates from studies with 
considerably higher mussel biomass than in our study, $1400 \mathrm{~g} \mathrm{~m}^{-2}$ (SFDW) giving a value of $12 \mathrm{~m}^{3} \mathrm{~m}^{-2} \mathrm{~h}^{-1}$ compared to our biomass of $128 \mathrm{~g} \mathrm{~m}^{-2}$ (SFDW). Butman et al. (1994) reported a filtration rate of a Mytilus edulis mussel bed in a flume to be $2.1 \mathrm{~m}^{3} \mathrm{~m}^{-2} \mathrm{~h}^{-1}$, with similar biomass, which is in the same range as our findings.

A previous study in the Öresund area over a 2 yr period (Edler 1977) found that there was a substantially lower biomass of phytoplankton at Kalkgrundet, which corresponds to this study's Stn 4 , compared to Ven, which corresponds to Stn 6 . These results were thus in accordance with the results of the present study.

\section{Plankton community structure}

It was found that the plankton community shifted towards more fast-growing algae as the hypothesis stated. The explanation for this - that faster-growing algae will successively dominate a community if there is no resource limitation - was tested with the modelling and not rejected. In this case the resources for growth were caused by intense non-selective grazing from mussels. Discussions of this ecological dogma were made by, for example, Furnas (1990) and Caraco et al. (1997). Modelling the plankton community shift clearly showed that the difference in growth rates alone could cause the community shift.

We modelled the community shift from Stn 0 to $\operatorname{Stn} 6$, and not just from Stn 0 to Stn 4, because we think that there was no resource limitation between the last 2 stations and hence a further shift in the community. Our argument for this is that the plankton biomass at Stn 6 did not reach the initial levels after the decline over the mussel bed.

The cellular volume is used as the base of allometric growth and not cellular carbon content, which should be a more proper value according to Tang (1995). In using the cellular volume, we exclude the importance of differing cellular carbon content between different phytoplankton groups, but still have a measurement of the growth rate versus cell volume. This is a simplified view of algal growth, since we do not account for the obvious differences in maximal growth rate among the phytoplankton groups. However, the basis of the hypothesis which was tested is: do smaller plankton algae, i.e. more fast growing, have a competitive advantage during intense non-selective grazing?

The blue mussel Mytilus edulis filters approximately $100 \%$ of the seston particles larger than $4 \mu \mathrm{m}$ and $80 \%$ of the particles larger than $2 \mu \mathrm{m}$ (Møhlenberg \& Riisgård 1978) but is unable to retain the picoplankton $(<1.0 \mu \mathrm{m})$ and the femtoplankton (bacteria $<0.2 \mu \mathrm{m})$, which thus has a growth advantage over the larger plankters (Wright et al. 1982). Wright et al. state: 'The contrast between clearance of phytoplankton and bacteria is evident: Blue mussels (and associated fauna as barnacles) removed a substantial proportion of the phytoplankton from water passing over the bed, but had no measurable effect on the bacterioplankton' This means that there could be a structuring force on the phytoplankton community by the selective filtering of the blue mussels in favour of a bacterial community. In this study we did not measure plankton smaller than $2 \mu \mathrm{m}$; thus it was not possible to evaluate this eventual rise of pico- and femtoplankton biomass. In the size fraction 2 to $4 \mu \mathrm{m}$, where there is a loss of efficiency. we calculated the degree of loss compared to the whole fraction 2 to $12 \mu \mathrm{m}$; from 2 to $4 \mu \mathrm{m}$ there is an increase in efficiency from 80 to $100 \%$; if we assume this increase to be linear, this size fraction loses $10 \%$ of its 'efficiency', which is only $2 \%$ in the whole size fraction 2 to $12 \mu \mathrm{m}$. This loss of filtering capacity for this size fraction, we argue, is negligible compared to the uncertainities from other sources (e.g. current speed and biomass).

In a laboratory experiment, the community structuring force by copepods was studied by Olsson et al. (1992). It was found that increased concentrations of copepods shifted the phytoplankton community to smaller algae. However, this was probably not a significant structuring force in this study compared to the high grazing of blue mussels. Our argument is that a survey made by Nicolajsen et al. (1983) in the Oresund area showed that less than 1 to $5 \%$ of the primary production was channelled through mesozooplankters during spring even without mussel grazing Another factor that could affect the plankton community structure is the grazing by ciliates; they could probably affect the picoplankton fraction because of their grazing and high growth rate (Banse 1982, Riegman et al. 1993). Riegman et al. (1993) concluded that protozooplankton (i.e. ciliates) could shift the plankton community to larger plankton such as diatoms and large dinoflagellates due to their size refuge as ciliate food. In this study there was a mean concentration of ciliates of 5000 cells $\mathrm{I}^{-1}$, mostly small Mesodinium rubrum and unidentified oligotrichous ciliates with a mean volume of $4200 \mu^{3}$ According to Jonsson (1986), a oligotrichous ciliate Strombidium vestitum with a volume of $9000 \mathrm{~mm}^{3}$ has a clearance rate (CR) of $0.52 \mathrm{\mu l} \mathrm{h}^{-1}$ ind $^{-1}$; if those values were used, a CR of the ciliates by approximately $2.6 \times 10^{-3} \mathrm{~m}^{3} \mathrm{~h}^{-1} \mathrm{~m}^{-3}$ would be found. This could be compared to the CR by the mussels, which is in the range of $0.55 \mathrm{~m}^{3} \mathrm{~h}^{-1} \mathrm{~m}^{-3}$ (calculated as $F_{\text {pop }}=4.4 \mathrm{~m}^{3} \mathrm{~h}^{-1} \mathrm{~m}^{-2}$ divided with the mean depth of $8 \mathrm{~m}$ ). Thus the grazing of ciliates was $0.5 \%$ of the mussel filtration, which was concluded as negligible. 
The community shift towards smaller and faster-growing algae makes an important prediction; if the phytoplankton community is changed towards faster-growing species, due to non-selective grazing, then the relative slow-growing large dinoflagellates would decline in abundance. This should, under certain circumstances, result in fewer toxic dinoflagellate species such as Dinophysis, which is the main factor for the distribution of DST (Diarrhetic Shellfish Toxin) in mussels, and Alexandrium, which causes PST (Paralytic Shellfish Toxin) in mussels. Can this mechanism explain why there are areas with a constantly lower concentration of phytoplankton toxins in the mussels such as in the Koljöfjord on the Swedish west coast (Lindegarth 1997)?

Acknowledgements. This work was supported by the Swedish MISTRA-Sustainable Coastal Zone Management project. We thank Peter Tiselius, Hans Ulrik Riisgård, LarsOve Loo, lain Barber, Jacob Hagberg, Bodil Hernroth, Erik Selander and Bengt Karlson for comments on the manuscript. We thank Björn Tunberg for valuable help.

\section{LITERATURE CITED}

Asmus RM, Asmus H (1991) Mussel beds: limiting or promoting phytoplankton? J Exp Mar Biol Ecol 148:215-232

Banse K (1982) Cell volumes, maximal growth rates of unicellular algae and ciliates, and the role of ciliates in the marine pelagial. Limnol Oceanogr 27(6):1059-1071

Butman CA, Fréchette M, Geyer WR, Starczak VR (1994) Flume experiments on food supply to the blue mussel Mytilus edulis L. as a function of boundary layer flow. Limnol Oceanogr 39(7):1755-1768

Caraco NF, Cole JJ, Raymond PA, Strayer DL, Pace ML, Findlay SEG, Fischer DT (1997) Zebra mussel invasion in a large, turbid river: phytoplankton response to increased grazing. Ecology 78(2):588-602

Carlson DJ, Townsend DW, Hilyard AL, Eaton JF (1984) Effects of an intertidal mudflat on plankton of the overlaying water column. Can J Fish Aquat Sci 41:1523-1528

Cohen RRH, Dresler PV, Phillips EJP, Cory RL (1984) The effect of the Asiatic clam, Corbicula fluminea, on phytoplankton of the Potomac River, Maryland. Limnol Oceanogr 29(1):170-180

Edler L (1977) Phytoplankton and primary production in the Sound. Göteborg University, Gothenburg

Fréchette M, Butrian CA, Geyer WR (1989) The importance of boundary-layer flows in supplying phytoplankton to the benthic suspension feeder, Mytilus edulis L. Limnol Oceanogr 34(1):19-36

Furnas MJ (1990) In situ growth rates of marine phytoplankton: approaches to measurement, community and species growth rates. J Plankton Res 12(6):1117-1151

Hansen G (1992) Biomasseberegninger. In: Thomsen HA (ed) Plankton i de indre danske farvand. Miljøstyrelsen, Copenhagen, p 20-34 (in Danish)

Jonsson PR (1986) Particle size selection, feeding rates and growth dynamics of marine planktonic oligotrichous ciliates (Ciliophora: Oligotrichina). Mar Ecol Prog Ser 33:265-277

Jørgensen CB (1990) Bivalve filter feeding: hydrodynamics, bioenergetics, physiology and ecology. Olsen \& Olsen, Fredensborg

Editorial responsibility: Otto Kinne (Editor).

Oldendorf/Luhe, Germany
Lavrentyev PJ, Gardner WS, Cavaletto JF, Beaver JR (1995) Effects of the zebra mussel (Dreissend polymorpha Pallas) on protozoa and phytoplankton from Saginaw Bay, Lake Huron. J Great Lakes Res 21(4):545-557

Lindegarth M (1997) Sammanställning och tolkning av de kontinuerliga mätningarna av okadasyrahalter längs den Svenska västkusten, 1989-1996. Report. Länstyrelsen Västra Götaland (in Swedish)

Loo LO, Rosenberg R (1989) Bivalve suspension-feeding and benthic-pelagic coupling in an euthrophicated marine bay. J Exp Mar Biol Ecol 130:253-276

Macisaac HJ, Sprules WG, Johannsson OE, Leach JH (1992) Filtering impacts of larval and sessile zebra mussels (Dreissena polymorpha) in Western Lake Erie. Oecologia 92:30-39

Møhlenberg $F$ (1995) Regulating mechanisms of phytoplankton growth and biomass in a shallow estuary. Ophelia 42: 239-256

Møhlenberg F, Riisgård HU (1978) Efficiency of particle retention in 13 species of suspension feeding bivalves. Ophelia 17(2):239-246

Nicolajsen H, Møhlenberg F, Kiørboe T (1983) Algal grazing by the planktonic copepods Centropages hamatus and Pseudocalanus sp.: diurnal and seasonal variation during the spring phytoplankton bloom in the Øresund. Ophelia 22:15-31

Nichols FH (1985) Increased benthic grazing: an alternative explanation for low phytoplankton biomass in northern San Francisco Bay during the 1966-1967 drought. Estuar Coast Shelf Sci 21:379-388

Olsson P, Granéli E, Carlsson P, Abreu P (1992) Structuring of a postspring phytoplankton community by manipulation of trophic interactions. J Exp Mar Biol Ecol 158:249-266

Prins TC, Escaravage V, Smaal AC, Peeters JCH (1995) Nutrient cycling and phytoplankton dynamics in relation to mussel grazing in a mesocosm experiment. Ophelia 41 : $289-315$

Riegman R, Kuipers BR, Noordeloos AAM, Witte HJ (1993) Size-differential control of phytoplankton and the structure of plankton communities. Neth J Sea Res 31(3): $255-256$

Riisgård HU, Rancløø A, Kristensen PS (1980) Rates of water processing, oxygen consumption and efficiency of particle retention in veligers and young post-metamorphic Mytilus edulis. Ophelia 19(1):37-47

Riisgård HU, Jensen AS, Jürgensen C (1998) Hydrography, near-bottom currents, and grazing impact of the filterfeeding ascidian Ciona intestinalis in a Danish fjord. Ophelia 49(1):1-16

Roditi HA, Caraco NF, Cole JJ, Strayer DL (1996) Filtration of Hudson River water by the zebra mussel (Dreissena poly morpha). Estukiries 19:824-832

SEMAC JV (1997) Myndighedernas kontrol-og overvågningsprogram for Øresundsförbindelsens kyst-till-kyst anlaeg. Blåmuslinger. Tillstandsrapport 1996. Øresundskonsortiet, Copenhagen (in Danish)

Tang EPY (1995) The allometry of algal growth rates. J Plankton Res 17(6): 1325-1335

Utermohl H (1958) Zur Vervollkomnung der quantitativen Phytoplankton-Methodik. Mitt Int Ver Limnol 9:1-38

Wright RT, Coffin RB, Ersing CP, Pearson D (1982) Field and laboratory measurements of bivalve filtration of natural marine bacterioplankton. Limnol Oceanogr 27(1): 91-98

Zeldis JR, Davis CS, James MR, Ballara SL, Booth WE, Chang FH (1995) Salp grazing: effects of phytoplankton abundance, vertical distribution and taxonomic composition in a coastal habitat. Mar Ecol Prog Ser 126:267-283

Submitted: February 1, 1999; Accepted: July 5, 1999

Proofs received from author(s): November 30, 1999 